\title{
ANALISIS AKUNTANSI PERTANGGUNGJAWABAN SEBAGAI EVALUASI KINERJA MANAJEMEN TERHADAP KLAIM BPJS DI RUMAH SAKIT PANCARAN KASIH MANADO
}

\author{
Jerikho Reagan Sumual ${ }^{1}$, Stanly W. Alexander ${ }^{2}$, Sintje Rondonuwu ${ }^{3}$ \\ ${ }^{1,2,3}$ Jurusan Akuntansi, Fakultas Ekonomi dan Bisnis, Universitas Sam Ratulangi, Jl. Kampus Bahu, Manado, \\ 95115, Indonesia \\ E-mail : regenegensumual@gmail.com
}

\begin{abstract}
Accounting accountability is an accounting system that recognizes the existence of responsibility centers in a company. Accounting information on accountability is urgently needed control in management as a means for communication, motivation and assessment. The purpose of this study is to know the effectiveness accountability as a means of evaluation of management performance against BPJS claims in Hospital Pancaran Kasih Manado. Type of research conducted in this study is qualitative research. From the results of research at Hospital Pancaran Kasih Manado shows that accounting as an evaluation of management performance in service claims BPJS has been effective by referring to the National Standard Accreditation Hospital
\end{abstract}

Keywords: Accounting Accountability, Management Performance

\section{PENDAHULUAN}

Akuntansi pertanggungjawaban merupakan sistem akuntansi yang mengakui adanya pusat - pusat pertanggungjawaban pada sebuah perusahaan. Akuntansi pertanggungjawaban timbul sebagai akibat adanya wewenang yang diberikan dan bagaimana mempertanggungjawabkannya dalam laporan tertulis. Laporan tersebut berupa prestasi kerja manajer untuk setiap pusat pertanggungjawaban dan pengendali biaya (Iswahyudi, 2007). Informasi akuntansi pertanggungjawaban sangat dibutuhkan pengendalian dalam manajemen sebagai sarana untuk komunikasi, motivasi dan penilaian. Sumarsan (2010:81) mendefinisikan akuntansi pertanggungjawaban sebagai setiap unit kerja dalam organisasi yang dipimpin oleh seorang manajer yang bertanggungjawab atas kegiatan-kegiatan dalam unit kerjanya. Manajemen bertanggungjawab untuk memastikan bahwa pekerjaan itu telah dilaksanakan, maka informasi akuntansi membantu pembentukan orang - orang dalam organisasi dan memotivasi agar bersedia melaksanakan setiap kebijakan manajer serta melakukan penilaian terhadap karyawan secara periodik untuk mengetahui sejauh mana pekerjaan telah dilaksanakan (Suwandi, 2008).

Akuntansi pertanggungjawaban yang baik, dalam penerapannya harus menetapkan atau memberi wewenang secara tegas, karena dari wewenang ini akan menimbulkan adanya tanggungjawab. Dengan wewenang dan tanggungjawab tersebut akan memudahkan pengendalian terhadap penyimpangan yang terjadi. Akuntansi pertanggungjawaban banyak di pakai oleh perusahaan dan badan usaha lainnya karena memungkinkan perusahaan untuk merekam seluruh aktivitas usahanya, kemudian mengetahui unit yang bertanggungjawab atas aktivitas tersebut, dan menentukan unit usaha mana yang tidak berjalan secara efisien (Viyanti, 2010).

Akuntansi pertanggungjawaban dalam hal ini sebagai evaluasi kinerja manajemen. Kinerja manajemen adalah suatu proses manajerial mengenai perencanaan, evaluasi dan penilaian kinerja perangkat organisasi untuk mewujudkan tujuan organisasi. Dengan penerapan manajemen kinerja kita dapat mengetahui apakah pekerjaan yang dilakukan 
selama ini sudah berada pada jalur yang seharusnya. Atau dengan kata lain, manajemen kinerja tidak hanya terkait dengan kinerja karyawan secara individu, tetapi juga kinerja organisasi secara keseluruhan. Fungsi manajemen kinerja adalah untuk penentuan sasaran yang jelas dan terarah. Di dalamnya terdapat tujuan organisasi yang ingin dicapai, strategi, rencana kerja dan saluran komunikasi atasan dan bawahan untuk memastikan pencapaian kinerja yang diharapkan (Mulyadi, 2001).

Kinerja manajemen juga dapat diterapkan dalam pelayanan rumah sakit. Pelayanan Rumah Sakit pada era sekarang tidak terlepas dari perkembangan ekonomi masyarakat. Perkembangan Rumah Sakit menjadikan pelayanan kesehatan lebih lengkap dan memuaskan dari mutu/kualitas layanan dan penanganan serta peralatan rumah sakit. Menurut Undangundang Nomor 24 Tahun 2011 Pasal 02 Tentang Badan Penyelenggara Jaminan Sosial (BPJS)

Syarat rumah sakit untuk bekerja sama dengan BPJS Kesehatan adalah melalui akreditas, untuk rumah sakit Pancaran Kasih Manado sudah mengkuti proses akreditasi dan tergolong rumah sakit berakreditas $\mathrm{C}$. Rumah sakit yang berakreditas $\mathrm{C}$ harus memiliki harus mempunyai fasilitas dan kemampuan pelayanan medik paling sedikit 4 (empat) Pelayanan Medik Spesialis Dasar dan 4 (empat) Pelayanan Spesialis Penunjang Medik. Mengacu pada Standar Akreditas Nasional Rumah Sakit (SNARS) pada Standar Manajemen Rumah Sakit ditetapkan kebijakan

1) Peningkatan Mutu Dan Keselamatan Pasien

2) Pencegahan dan Pengendalian Infeksi

3) Tata Kelola Rumah Sakit

4) Manajemen Fasilitas Dan Keselamatan

5) Kompetensi Dan Kewenangan Staf

6) Manajemen Informasi dan Rekam Medis

Setelah di lakukannya observasi pendahuluan yang di lakukan oleh peneliti, faktanya tidak semua pasien di rumah sakit Pancaran Kasih Manado mengetahui bagaimana prosedur klaim BPJS. Mengingat banyaknya pasien yang ada di rumah sakit milik swasta ini jika proses klaim BPJS terhambat karena adanya pasien yang kurang mengerti dalam proses klaim BPJS itu bisa mempengaruhi kinerja manajemen pihak Rumah Sakit. Akuntansi pertanggungjawaban disini mimiliki peranan yang penting untuk membantu kinerja manajamen untuk menilai keefektifitasnya.

Akuntansi pertanggungjawaban pada hakekatnya adalah suatu sistem yang membandingkan rencana (anggaran) dengan realisasinya dari setiap pusat pertanggungjawaban untuk mengukur kinerja seseorang atau manajemen untuk mencapai tujuan dari organisasi/perusahaan. Informasi akuntansi pertanggung jawaban sangat berguna dalam pengendalian manajemen sebagai sarana untuk komunikasi, motivasi, dan penilaian. Manajemen bertanggungjawab untuk memastikan bahwa pekerjaan itu telah dilaksanakan, maka informasi akuntansi membantu dalam pengendalian biaya. Badan layanan umum yang menerapkan akuntansi pertanggungjawaban akan membentuk pusat-pusat pertanggungjawaban

Berdasarkan uraian diatas peneliti tertarik untuk melakukan penelitian di Rumah Sakit Pancaran Kasih Manado dengan mengangkat judul "Analisis Akuntansi Pertanggungjawaban Sebagai Evaluasi Kinerja Manajemen Terhadap Pelayanan Klaim BPJS di Rumah Sakit Pancaran Kasih Manado".

Berdasarkan latar belakang penelitian, maka rumusan masalah pada penelitian ini sebagai berikut:

Apakah akuntansi pertanggungjawaban pusat biaya sebagai sarana evaluasi kinerja manajemen terhadap klaim BPJS di Rumah Sakit Pancaran Kasih Manado sudah tergolong efektif ? 


\section{TINJAUAN PUSTAKA}

\subsection{Akuntansi Pertanggungjawaban}

Akuntansi pertanggungjawaban didasarkan pada pemikiran bahwa seorang manajer harus dibebani tanggung jawab atas kinerjanya sendiri dan kinerja bawahannya. Menurut Mulyadi (2001:218) Akuntansi pertanggungjawaban adalah suatu sistem akuntansi yang disusun sedemikian rupa sehingga pengumpulan dan pelaporan biaya dan pendapatan dilakukan sesuai dengan pusat pertanggungjawaban dalam organisasi, dengan tujuan agar dapat ditunjuk orang atau kelompok orang yang bertanggung jawab atas penyimpangan biaya dan pendapatan yang dianggarkan.

Definisi tersebut mengatakan bahwa akuntansi pertanggungjawaban mengelompokkan organisasi atas pusat-pusat pertanggungjawaban, sehingga apabila terjadi penyimpangan atas anggaran, maka pihak manajemen dapat mencari orang yang bertanggungjawab atas penyimpangan yang terjadi. Akuntansi pertanggungjawaban bukan hanya untuk menunjukkan terjadinya penyimpangan biaya yang diperlihatkan dalam laporan kinerja manajer, tetapi yang terutama adalah sebagai manfaat dengan memberi informasi bagaimana kegiatan yang menjadi tugas manajer pusat pertanggungjawaban dilakukan. Melalui informasi ini diharapkan akan timbul motivasi bagi manajer untuk bekerja lebih efektif dan efisien serta dapat melakukan tindakan korektif yang diperlukan agar hasil yang diperoleh merupakan yang terbaik dengan tidak mengesampingkan tujuan perusahaan.

Dapat disimpulkan bahwa akuntansi pertanggungjawaban merupakan suatu sistem

yang digunakan oleh perusahaan untuk mengevaluasi kinerja pusat-pusat pertanggungjawaban dan memudahkan pengendalian atas hasil dan biaya yang menjadi tanggung jawab manajer yang bersangkutan.

Menurut Harahap (2001:169) syarat-syarat penerapan akuntansi pertanggungjawaban yang baik adalah:

a. Memiliki struktur organisasi yang baik. Struktur organisasi yang baik artinya memiliki batasan terhadap wewenang dan tanggungjawab yang tegas dan jelas sehingga setiap bagian dengan bagian lain tidak merasa bingung.

b. Memberikan sistem reward dan punishment berdasarkan standart pertanggungjawaban yang ditetapkan.

c. Memiliki sistem akuntansi yang sejalan dan disesuaikan dengan pusat pertanggungjwaban.

d. Anggaran atau budget harus disusun menurut pusat-pusat pertanggungjawaban. Anggaran harus disusun sesuai dengan tingkatan manajemen dalam organisasi yang diatur dalam sistem pertanggungjawaban.

e. Terdapat sistem pelaporan pendapatan dan biaya dari manajer yang sesuai dengan tanggungjawabnya.

f. Untuk akuntansi pertanggungjawaban biaya,harus tedapat pemisahan antara biaya yang dapat dikendali (controllable) dengan yang idak dapat dikendali (uncontrollable) oleh manajer pusat pertanggungjawaban yang bersangkuatan.

g. Harus ada akibat baik berupa penghargaan reward maupun penalties sebagai akibat prestasinya sesuai dengan ukuran tanggungjawabnya.

Dari keterangan di atas dapat disimpulkan bahwa penerapan akuntansi pertanggungjawaban yang baik harus memiliki syarat yang telah ditentukan. Jika salah satu syarat yang ada tersebut ada yang tidak terpenuhi maka sistem akuntansi pertanggungjawaban tersebut tidak sempurna, sehingga harus ada perbaikan-perbaikan untuk menyempurnakannya.

\subsection{Kinerja Manajemen}

Kata manajemen kinerja merupakan penggabungan dari kata manajemen dan kinerja. Manajemen berasal dari kata to manage yang berarti mengatur. Menurut George R Terry 
dalam bukunya Principles of Management, Manajemen merupakan suatu proses yang menggunakan metode ilmu dan seni untuk menerapkan fungsi-fungsi perencanaan, pengorganisasian, pengarahan dan pengendalian pada kegiatan-kegiatan dari sekelompok manusia yang dilengkapi dengan sumber daya/faktor produksi untuk mencapai tujuan yang sudah ditetapkan lebih dahulu, secara efektif dan efisien. Sedangkan menurut John R Schermerhorn Jr dalam bukunya Management, manajemen adalah proses yang mencakup perencanaan, pengorganisasian, pengarahan dan pengendalian terhadap penggunaan sumber daya yang dimiliki, baik manusiadan material untuk mencapai tujuan. Dari beberapa definisi manajemen yang diberikan oleh para ahli, dapat disimpulkan manajemen mencakup tiga aspek, yaitu:

a. Pertama : manajemen sebagai proses

b. Kedua : adanya tujuan yang telah ditetapkan

c. Ketiga : mencapai tujuan secara efektif dan efisien

\subsection{Standar Nasional Akreditas Rumah Sakit}

Akreditasi Rumah Sakit di Indonesia dilaksanakan untuk menilai kepatuhan rumah sakit terhadap standar akreditasi. Akreditasi rumah sakit yang sudah mulai dilaksanakan sejak tahun 1995 di Indonesia, selama ini menggunakan standar akreditasi berdasarkan tahun berapa standar tersebut mulai dipergunakan untuk penilaian, sehingga selama ini belum pernah ada Standar Nasional Akreditasi Rumah Sakit di Indonesia, sedangkan status akreditasi saat ini ada status akreditasi nasional dan status akreditasi internasional, maka di Indonesia perlu ada Standar Nasional Akreditasi Rumah Sakit.

Standar dikelompokkan menurut fungsi-fungsi penting yang umum dalam organisasi perumahsakitan. Pengelompokan berdasarkan fungsi, saat ini paling banyak digunakan di seluruh dunia. Standar dikelompokkan menurut fungsi-fungsi yang terkait dengan penyediaan pelayanan bagi pasien; juga dengan upaya menciptakan organisasi rumah sakit yang aman, efektif, dan terkelola dengan baik. Fungsi-fungsi tersebut tidak hanya berlaku untuk rumah sakit secara keseluruhan tetapi juga untuk setiap unit, departemen, atau layanan yang ada dalam organisasi rumah sakit tersebut. Lewat proses survei dikumpulkan informasi sejauh mana seluruh organisasi mentaati pedoman yang ditentukan oleh standar. Keputusan pemberian akreditasinya didasarkan pada tingkat kepatuhan terhadap standar di seluruh organisasi rumah sakit yang bersangkutan.(Komisi Akreditas Rumah Sakit 2017).

\section{METODE PENELITIAN}

Penelitian kualitatif lebih menitik beratkan terhadap pengulasan suatu fenomena dan permasalahan secara utuh melalui kata-kata dan bukan menggambarkan fenomena tersebut melalui angka. Tujuan kualitatif menurut Sahlan (2012) adalah untuk memahami fenomena atau gejala sosial dengan menitik beratkan pada gambaran yang lengkap tentang fenomena yang di kaji daripada merincinya menjadi variabel-variabel yang saling terkait. Dimana tujuan tersebut sejalan dengan tujuan dari penelitian yang akan dilakukan. Tujuan dari penelitian ini adalah untuk mengetahui bagaimana penerapan akuntansi pertanggungjawaban sebagai sarana evaluasi kinerja manajemen terhadap klaim BPJS di rumah sakit Pancaran Kasih Manado sudah tergolong efektif.

Penelitian ini juga termasuk dalam penelitian studi kasus (case study), karena penelitian hanya berfokus terhadap penerapan akuntansi pertanggungjawaban disalah satu perusahaan Arikunto (2005:41) menyebutkan penelitian kasus sebagai suatu penelitian yang dilakukan secara in tensif, terinci dan mendalam terhadap suatu organisai, lembaga atau gejala tertentu. Ditinjau dari segi keluasan wilayah penelitian, studi kasus hanya dilakukan pada wilayah yang sempit, akan tetapi dengan sifat yang lebih mendalam. Lokasi penelitian dilaksanakan di Rumah Sakit Pancaran Kasih Manado. Waktu penelitian dilaksanakan selama dua bulan. Data kualitatif yang digunakan dalam penelitian ini yaitu berupa gambaran 
umum objek penelitian dan data tentang analisis akuntansi pertanggungjawaban sebagai evaluasi kinerja Manajemen terhadap pelayanan klaim BPJS di rumah sakit Pancaran Kasih Manado.

Metode Analisis data yang digunakan dalam penelitian ini adalah metode analisis kualitatif deskriptif, yaitu peneliti mendeskripsikan hasil temuannya yang berasal dari datadata yang terkumpul melalui proses observasi di obyek penelitian yang kemudian akan diperbandingkan dengan metode penerapan akuntansi pertanggungjawaban secara teori yang selama ini berkembang dikalangan akademik. Peneliti kemudian menganalisis kesesuaian metode akuntansi pertanggungjawaban yang diperbandingkan secara setahap demi tahap dalam penerapan akuntansi pertanggungjawaban tersebut pada masing-masing metode dengan analisis deskripsi komparatif yang diinterpretasikan atas dasar data yang ada.

\section{HASIL ANALISIS DAN PEMBAHASAN \\ 4.1. Hasil Analisis}

\section{a. Laporan Akuntansi Pertanggungjawaban Pada Rumah Sakit Pancaran Kasih}

Untuk membantu para pemakai laporan akuntansi pertanggungjawaban dalam mengetahui pelaporan biaya dan pendapatan dilakukan sesuai dengan pusat pertanggungjawaban disusunlah laporan akuntansi pertanggungjawaban yang ada di Rumah Sakit Pancaran Kasih. Informasi akuntansi pertanggungjawaban berguna pada Rumah Sakit Pancaran Kasih karena menekankan pada hubungan antara informasi dengan manajer yang bertanggungjawab terhadap perencanaan dan pelaksanaan.

Rumah Sakit Pancaran Kasih Manado menampilkan jumlah laba bruto tahun 2015 sebesar Rp.55.737.769.191 sedangkan jumlah laba netto tahun 2015 sebesar Rp. 66.583.677. Dari hasil wawancara yang dilakukan peneliti dengan kepala keuangan di Rumah Sakit Pancaran Kasih Manado dalam kegiatan operasionalnya melakukan pemisahan biaya terkendali dan tidak terkendali. Biaya terkendali merupakan biaya yang jumlahnya selalu sama dan cenderung tidak berubah serta dapat dikendalikan secara langsung. Sedangkan biaya tidak terkendali adalah biaya yang cenderung berubah dan tidak tetap serta sulit dikendalikan karena dipengaruhi oleh harga pasar.

\section{b. Kinerja Manajemen Terhadap Klaim BPJS pada Rumah Sakit Pancaran Kasih Manado}

Pengembangan sumber daya manusia pada dasarnya merupakan penigkatan kinerja karyawan yang mencerminkan kemampuan anggota organisasi dalam bekerja, artinya kinerja masing-masing karyawan dinilai dan diukur menurut kriteria yang sudah ditentukan. Kinerja seorang karyawan didalam organisasi tentunya tidak terlepas dari kepribadian, kemampuan serta motivasi karyawan tersebut dalam menjalankan aktivitas-aktivitas yang dilakukannya dalam tugas dan pekerjaannya.

Pada Rumah Sakit Pancaran Kasih Manado memiliki manajemen yang bertugas terhadap klaim BPJS yang diajukan oleh pasien. Alur Klaim BPJS menunjukkan bagaimana kinerja manajemen dalam mengikuti alur klaim BPJS dilihat dari setiap alur yang dijadikan acuan dalam kinerja manajemen sangat terperinci..

\subsection{Pembahasan}

Analisis Akuntansi Pertanggungjawaban Pusat Biaya Terhadap Kinerja Manajemen Pada Klaim BPJS di Rumah Sakit Pancaran Kasih Manado

Dari analisis laporan pertanggungjawaban dengan menggunakan laporan laba rugi Rumah Sakit Pancaran Kasih tahun 2015 secara keseluruhan menunjukan hasil favourable (menguntungkan). Hal ini dikarenakan rumah sakit telah memisahkan biaya terkendali dan tidak terkendali dalam operasionalnya. Akuntansi pertanggungjawaban mengfokuskan terhadap pembagian wewenang kepada pemimpin yang bertanggungjawab. Akuntansi pertanggungjawaban berperan sebagai alat pengendalian biaya dengan menghubungkan biaya 
dengan bagian dimana biaya tersebut dikeluarkan atau diperoleh oleh pimpinan yang bertanggungjawab pada bagian tersebut. Pelaksanaan perencanaan dan pengendalian dalam suatu organisasi memerlukan sistem akuntansi pertanggungjawaban.

Dengan melihat laporan laba rugi rumah sakit Pancaran Kasih Manado pada tahun 2015 dapat menjadi acuan dalam pengendalian biaya sebagai pertanggungjawaban manajemen. Penelitian ini difokuskan pada pusat biaya untuk menilai penerapan akuntansi pertanggungjawaban.

Terdapat berbagai klasifikasi biaya yang dijabarkan dalam laporan laba rugi pada Rumah Sakit Pancaran Kasih Manado pada tahun 2015 seperti, biaya yang dikeluarkan untuk gaji pegawai dan honor sebesar adalah sebesar Rp. 9.287.100.899 serta biaya untuk rekening telepon sebesar Rp. 39.691 .986 biaya listrik sebesar Rp. 555.082.660 biaya administrasi sebesar Rp. 516.986.043 biaya transportasi sebesar Rp. 171.907.500 biaya makan pasien dan karyawan sebesar Rp. 1.421.359.503 biaya pemeliaraan sebesar Rp. 1.819.945.038 biaya pengembalian panjar Rp. 21.316.067 biaya pensiunan sebesar Rp.613.396.805 dan biaya lain - lain sebesar Rp. 41.224.399.013 dengan jumlah total Rp. 55.671.185.514 serta total pendapatan sebesar Rp. 60.061.836.708 biaya langsung yaitu pembelian obat dan alat medik sebesar Rp. 4.324.067.517. Dalam laporan tersebut menunjukan hasil laba netto sebesar Rp. 66.583.677 dengan bruto sebesar Rp. 55.737.769.191 dengan demikan hasil dari laporan laba rugi pada Rumah Sait Pancaran Kasih Manado tahun 2015 menunjukan keuntungan, oleh sebab itu bisa dikatakan manajemen telah bekerja dengan baik dalam mengalokasikan biaya dan pendapatannya

Seperti yang sudah terterah dalam hasil peneletian prosdur klaim BPJS, pertama pasien melengkapi berkas dan permintaan dari BPJS ke rumah sakit baik untuk rawat jalan atau rawat nginap setelah memeriksakan diri di poliklinik pasien akan di periksa apakah mengalami tunggakan iuran. Iuran yang dibayarkan tergantung kelas yang dipilih oleh peserta BPJS. Berdasarkan Peraturan Presiden Nomor 19 Tahun 2016 tentang Perubahan Kedua atas Peraturan Presiden Nomor 12 Tahun 2013 tentang Jaminan Kesehatan, iuran BPJS resmi mengalami kenaikan,untuk iuran BPJS kelas III awalnya Rp. 25.500. menjadi Rp. 30.000 (khusus kelas 3 kenaikan dibatalkan jadi tetap besarnya Rp. 25.500 sesuai diterbitkannya pp nomor 28 tahun 2016 revisi ketiga atas pp no 12 tahun 2013) dan kelas II yang awalnya Rp. 42.500 menjadi Rp. 51.000 serta kelas I iuran bulanan yang harus dibayar awalnya Rp. 59.500 menjadi Rp. 80.000 .

Sebelum masuk dalam penginputan INA-CBG pasien akan dibuat resume medis baik rawat inap atau rawat jalan, salah satu tujuan dibuat lembar resume adalah untuk memenuhi permintaan dari badan - badan resmi atau perorangan tentang perawatan seorang pasien, misalnya dari perusahaan asuransi (dengan persetujuan Pimpinan). Lembar resume merupakan lembaran pada bagian akhir catatan perkembangan atau dengan lembaran tersendiri yang singkat dan menjelaskan informasi penting tentang penyakit, pemeriksaan yang dilakukan dan pengobatannya serta harus ditulis segera setelah pasien keluar. Resume medis ini di gunakan sebagai dasar penentuan koding di paket INA-CBGs. Koding Diagnosis merupakan suatu proses pengklasifikasian data (diagnoses) dan penentuan code (sandi) nomor/alfabet/ atau alfanumerik untuk mewakilinya. Kemudian masuk dalam verifikator internal dan pada tim casemix, tugas tim casemix adalah untuk menerima dan memeriksa kembali berkas jaminan yang masuk dan membantu kegiatan dalam proses clinical pathway di Instalasi Rawat Jalan, Rawat Inap, Instalasi Gawat Darurat, maupun Kamar Operasi untuk memberikan informasi besaran target dan besaran tarif paket INA-CBGs dengan melakukan coding diagnosis serta prosedur medis dan grouping pada Server Software simulasi INA-CBGs, serta melakukan medical record analysing atau menganalisis berkas klaim dengan memastikan kelengkapan isi rekam medis dan menerjemahkan bahasa diagnosis, membuat daftar 
diagnosis dan tindakan medis lalu menginput data pada variabel yang ada pada softwere INACBGs. Setelah di input di INA-CBGs lalu dilakukan pengajuan klaim.

Dari standar yang di tetapkan Standar Nasional Akreditas Rumah Sakit (SNARS) dan hasil observasi yang dilakukan Rumah Sakit Pancaran Kasih Manado sudah tergolong efektif karena telah memenuhi standar yang ditetapkan pengelolaan tetapi dalam penyampaian data dan pembaharuan beberapa data pihak manajemen rumah sakit yang terdapat pada point yang ke lima dalam tabel kurang memenuhnya meskipun demikian secara kesulurahan rumah sakit sudah tergolong efektf, dalam pendapatan juga pihak manajemen rumah sakit dalam mempertaggungjawabannya sudah tergolong baik melihat dari laporan laba rugi rumah sakit yang memperoleh keuntungan.

\section{KESIMPULAN DAN SARAN \\ 5.1 Kesimpulan}

Rumah Sakit Pancaran Kasih Manado dalam pelayanannya telah menjalin kerja sama dengan BPJS Kesehatan. Pelayanan dalam klaim BPJS dari pasien ke rumah sakit telah menunjukan hasil yang efektif di dilihat dari standar yang ditetapkan oleh Standar Nasional Akreditas Rumah Sakit (SNARS). Dalam pengjuan klaim BPJS pihak rumah sakit telah mengikuti alur dan prosedur BPJS yang ditetakan dan diterapkan dengan baik oleh pihak manajemen rumah sakit.

Secara umum akuntansi pertanggungjawaban pada Rumah Sakit Pancaran Kasih Manado di tunjukan pada laporan laba rugi rumah sakit pada tahun 2015 memperoleh keuntungan. Pihak rumah sakit telah melakukan pemisahan pada biaya terkendali dan tidak terkendali, namun dalam pengumpulan data serta pembaharuan data pihak rumah sakit kurang memenuhinya, untuk mengoptimalkan manajemen dari rumah sakit ada baiknya pihak manajemen melakukan pembaharuan data agar rumah sakit tidak ketinggalan dan ini juga bisa membantu dalam akreditas rumah sakit.

Dari segi pelayanan untuk BPJS manajemen rumah sakit sudah baik dalam melakukanya, mengingat Rumah Sakit Pancaran Kasih merupakan tempat registrasi awal dimana setiap pasien yang akan menggunakan klaim BPJS harus melewati Rumah Sakit Pancaran Kasih Manado dulu untuk melakukan pemeriksaan awal lalu kemudian tahap selanjutnya akan dipertimbangkan apakah akan dirujuk ke rumah sakit lain atau tidak kecuali untuk pasien UGD.

\subsection{Saran}

Saran yang dapat penulis kemukakan dalam peneltian ini adalah sebagai berikut :

1. Sebaiknya rumah sakit melakukan pengumpulan data dan pembaharuan data agar dapat mempermudah rumah sakit dalam proses akreditas mengingat Rumah Sakit Pancaran Kasih Manado adalah rumah sakit yang berakreditasi C.

2. Rumah Sakit juga dapat memberikan tanda atau arahan untuk pasien agar dalam proses klaim BPJS pasien dapat lebih mudah untuk memahami dan mengert dalam melakukan klaim BPJS.

\section{DAFTAR PUSTAKA}

Amstrong, M., \& Angela, B. (2004). Manajemen Kinerja.

Arikunto S, 2005. Manajemen Penelitian. Jakarta: Rineka Cipta

Hansen., Mowen. 2005. Management Accounting. Buku 2.Edisi ke 7. Salemba Empat. Jakarta

Harahap, SofyanSyafri, 2001, Analisis Kritis Atas Laporan Keuangan, Cetakan Kedua, Jakarta PT. Raja Grafindo Persada. 
Horngren, C. T., \& Harrison, W. T. (1993).Accounting. Prentice hall.

Moleong, Lexy J.2011. Metodologi Penelitian Kualitatif. Bandung: PT Remaja Rosdakarya

Mulyadi, J. S. (2001). Sistem Perencanaan dan Pengendalian Manajemen. Yogyakarta: Aditya Media.

Romney, M., \& Paul, J. Steinbart.(2006). Accounting information system

Sahlan, S. H. S. Pd. I. Tujuan Utama Penelitian Kualitatif. 2012.

Sumarsan 2010 Sistem Pengendalian Manajemen PT Indeks Jakarta

Suwandi, S. (2008). Penelitian Tindakan Kelas (PTK) dan Penulisan Karya Ilmiah.Surakarta: Panitia Sertifikasi Guru Rayon, 13

Viyanti.2010 Akuntansi Pertanggungjawaban Sebagai Alat Pengendalian Manajemen Terhadap Penilaian Prestasi Kerja Akurat Jurnal Ilmiah Akuntansi No.3 Tahun Ke-1 September - Desember 2010. Universitas Kristen Maranatha. Bandung. 